\title{
Influence of Employee Competencies Management on Employee Performance in Public Universities in Kenya
}

\author{
Billiah Millicent Maende Wario Guyo Romanus Odhiambo Renson Muchiri Mwangi \\ KCA University ${ }^{2} \&^{3}$ Jomo Kenyatta University of Agriculture and Technology
}

\begin{abstract}
Globalization, the proliferations of technology, workforce diversity, and the knowledge society have sparked a wave of learning, training and workplace education in organizations from all sectors. Descriptive research design was applied to examine the influence of employee competencies on employee performance in public universities in Kenya. Descriptive and inferential statistics analyzed the data. It was found that there was positive and significant influence of employee competencies management on employee performance in public universities in Kenya.
\end{abstract}

Keywords: Employee Competencies management, Employee Performance

DOI: $10.7176 / \mathrm{EJBM} / 11-21-13$

Publication date:July $31^{\text {st }} 2019$

\section{Introduction}

The advent of the Internet, the World Wide Web, has made unlimited sources of knowledge available and experts now recognize the dawn of the knowledge age taking over from the Industrial Era, (Schiuma, 2012). Globalization, the proliferations of technology, workforce diversity, and the knowledge society have sparked a wave of learning, training and workplace education in organizations from all sectors. Complex workplace interactions now typically "...require people to regularly deal with ambiguity and solve problems based on experience or tacit knowledge" (Sauve, 2007: 1). The consequence of this trend is the emergence of knowledge-based economies where importance is placed on effective management of human capital to ensure that workers continue to create the right value for the economy, (Omotayo, 2015). Around the world the workforce is rapidly changing, and dynamics are altering how organizations perceive the acquisition, use and generation of knowledge. Workplaces have evolved from preindustrial apprenticeships to large scale, specialized, and segmented organizations, with defined employee roles and responsibilities, (Ibua, 2014).

A core competency is a concept in management theory introduced in 1990s by scholars who defined it as a harmonized combination of multiple resources and skills that distinguish a firm in the marketplace, (Prahalad \& Hamel, 1990). According to Boyatzis (2008), competency can be defined as an underlying characteristic of a person which results in superior and/or effective performance in a job. The litmus test for a core competency is that it is hard for competitors to copy or procure, (Alai, Kramer \& Montier. 2006). According to (Kodwani, 2009), performance is the mantra of today's business organization and it is only the people with right abilities who are able to perform better. Competencies are an important element determining the current professional potential of employees and its impact on intellectual capital, (Prusak, 2013).

Employee competencies are those traits, skills or attributes that employees need to perform their jobs most effectively. Clearly, these competencies will vary by job and position, but there are some commonalities that apply to just about any job in just about any organization, (Garvey, 2013). Employee competencies management as a KM practice therefore focuses on the value of human capital which largely depends on the level of involvement of employees, the extent to which they want and can use their own potential to achieve the objectives of the company, (Alessandria \& Secundo, 2009).

The key factor in this context is to provide an adequate level of motivation and job satisfaction of employees that may follow a synergistic impact of organizational culture, management style, conditions and content of work, relationships and incentives as part of the incentive system, (Lukasiewicz 2009). As a KM practice, it is important to summarize a brief overview of how employee competencies are managed: First is identification and assessment of employee core competencies by an organization mapping out its key competencies, possibly linking them directly to specific core products, carry out an evaluation on its relevance, (Kodwani, 2009). Consequently, the paper evaluated the influence of employee core competencies

\section{Theoretical and Empirical Literature}

\subsection{Intellectual Capital Theory}

Knowledge is the main asset of the new economy hence its management and protection have become part of the competitive strategies of organizations in the recent past (Passi, Luoma \& Valkokari, 2010). This legal concept embodies a theory that emphasizes the value of knowledge within the organization. The physical capital of an organization, particularly in the service sector, is of less relative importance for competitive advantage than intangible assets like know-how and personal sales networks. The market value of many service organizations like 
universities is far higher than the value of their physical capital to be characterized as 'goodwill' (Roos \& von Krogh, 1996). Intellectual capital has been defined as the difference between the book value of the company and the amount of money someone is prepared to pay for it, (Wiig, 1997).

Intellectual capital theory is about assets: assets like trademarks and customer loyalty that give the company power in the marketplace; assets like patents and copyrights that give the company property rights 'of the mind'; assets like corporate culture, structure, and information technology style that give the company internal strength; and assets like employees' knowledge and personal networks that enable company processes (Brooking, 1997). Organizational knowledge is viewed as a capital asset. This view implies that knowledge management regards balancing a knowledge portfolio. Thereafter, the portfolio is coordinated and exploited for maximized return-oninvestment, (Baskerville \& Dulipovici, 2006).

The most widely used definition of intellectual capital is "knowledge that is of value to an organization" (Bassi, 1997). That definition suggests that the management of knowledge (the sum of what is known) creates intellectual capital. Components of intellectual capital consist of human capital, structural capital and external (customer) capital, Ulrich, (1998). Human capital is defined as the knowledge, skills, experience, intuition and attitudes of the workforce. Intellectual capital can be increased by increasing the capacity of each worker, Tapsell, (1998). Human capital is the knowledge, skill and capability of individual employees providing solutions to customers. It is the firm's collective capability to extract the best solutions from the knowledge of its people. It is important because it is a source of new ideas and competitiveness.

According to Sveiby, (1999), individual competence translates to employees' ability to react to changes as they occur and includes skill, education, experience, values and social skills. People create knowledge, new ideas, and new products, and they establish relationships that make processes function. It is important to manage the knowledge that the employees possess because when they leave, they take along their knowledge, including internal, external, formal, and informal relationships, (Brenner, 1999). The commitment and competence is embedded in their perceptions and actual performance of their work and the manner in which organizations create polices and systems that work, determines the success of knowledge management, (Ulrich, 1998).

Human capital then becomes important because: first, intellectual capital is a firm's only appreciable asset. Most other assets (building, plant, equipment, machinery, and so on) begin to depreciate the day they are acquired. Intellectual capital must grow if a firm is to prosper. Second, knowledge work is increasing, not decreasing. Third, employees with the most intellectual capital have essentially become volunteers, because the best employees are likely to find work opportunities in a number of firms. This does not mean that employees work for free, but that they have choices regarding where they work and, therefore, it important to effectively manage the knowledge they possess by building their commitment and loyalty.

\subsection{Employee Competencies management and Employee Performance}

Competencies are the measurable or observable knowledge, skills, abilities and behaviors (KSABs) critical to successful job performance (Stockley, 2007). It is the ability of an individual to do a job properly. Competency can also be viewed as a set of defined behaviors that provide a structured guide enabling the identification, evaluation and development of the behaviors in individual employees, (Eicker, Kochbeck \& Schuler, 2014).

A study by Zaim, Yasai \& Unal, (2013) investigated the effects of individual competencies on performance in the services industries in Turkey. Findings revealed that there is a positive relationship between competencies and individual performance. The study further revealed that management of competencies are a significant factor towards individual performance since it provides job satisfaction and commitment and intention to remain with the organization.

A study by Prusak (2013) investigated the impact of employee competencies management as part of the intellectual capital implementing process in 70 companies. The study concluded that competencies are an important element determining the current professional and potential of employees and its impact on intellectual capacity. The study further revealed that the activation of competence requires the existence of certain environmental stimuli and internal mental processes of the holder. The activities of the company such as the design of effective motivation schemes and proper organization of work patterns have a huge impact on the utilization level of competence and efficiency of workers. The results presented in the study apply only to a few selected aspects of the relationship between competence management and employee performance, and can therefore be applied to make broader conclusions and generalizations about the relationship.

A study by Murtaza, (2015) investigated the gap between employee competencies that existed and those required in the Tourism sector in India and concluded that efficient management of these competencies enhances the functions of the various departments and contributes positively to the overall performance and satisfaction of the employees. The results supported investing of time and money in staff development, aimed at enhancing employee competencies in order to achieve higher performance.

A study by Ngesa et al. (2014) on the influence of performance management practices on employee engagement in public universities in Kenya indicated that there is a positive correlation between performance 
management review and employee engagement in these institutions. As a KM practice, management of employee competencies starts with identification competencies currently available and matching them to what is required. The build-up of these skills and competencies must often be managed according to long-term strategic goals and coordinated across the organization, so as to influence employee performance (Cranefield \& Taylor, 2011). Knowledge assets must be built, enhanced, combined, and coordinated in an environment that supports experimentation and improvement. This may be done through re-training, restructuring, creating new knowledge flows, external knowledge acquisition, outright removal of irrelevant or outdated knowledge and others, (Zook, 2007).

\section{Research Methodology}

\subsection{Research Design}

Research design is the conceptual structure within which research is conducted; it constitutes the blueprint for the collection, measurement and analysis of data, (Kothari 2013). Further, Oso and Onen (2009) posits that through descriptive research design, questions pertinent to what is happening, how it has happened and why it has happened can be answered. Cooper and Schindler (2011), further indicates that a descriptive study is concerned with finding out the what, where and how of a phenomenon. The study used descriptive research design since it will enable the researcher generalize the findings to a larger population to obtain information concerning the current status of the phenomena and to describe "what exists".

\subsection{Target Population}

The complete enumeration of all the elements under consideration in a study is known as target population, (Polit \& Beck, 2004). According to Commission for University Education (CUE) website (www.cue.or.ke), Kenya has 31 public chartered Universities. The target population was drawn from employees working in the 10 chartered public universities in Kenya which is estimated at 495 based on information obtained from the university websites. The unit of analysis was 10 selected public universities using the criteria of those which have been in existence for more than 10 years.

\subsection{Sampling Frame and Techniques}

A sampling frame is a complete list of all the members of the population that we wish to study. Sample is a subset of the total population which is selected to be the true representative of the target population. A sample is selected through sampling process (Oso \& Onen, 2009). Sampling technique can be either probabilistic or non-probabilistic, in the former there are equal chances of being selected while in the latter the respondent is selected through subjective criteria (Kothari, 2013). The study used stratified sampling method that uses a stratum which is a subset of the population that shares at least one common characteristic, (Kothari, 2013). This technique allows the researcher to perform a sound study on a small sample selected to provide information which is rich in qualitative context in order to answer research questions and meet objectives. Additionally, the method has a higher statistical precision compared to simple random sampling because the variability within the subgroups is lower compared to the variations when dealing with the entire population. This also means that it requires a small sample size which can save a lot of time, money and effort of the researchers. The sample size for students was calculated based on Yamane's formula (Yamane, 1967).

$\mathrm{n}=\mathrm{N} /\left(1+\mathrm{N}^{*} \mathrm{e}^{2}\right)$; where, $\mathrm{n}=$ the sample size, $\mathrm{N}=$ the size of population, $\mathrm{e}=$ the error of 5 percentage points; $\mathrm{n}=495 /\left(1+495^{*} 0.05^{2}\right) \quad \mathrm{n}=221$. By using Yamane formula with sampling error of $5 \%$ and $95 \%$ confidence intervals yielded a sample of 221 from a target population of 495. Resultant sample from each stratum will be distributed as shown in Table 3.1.

Table 3.1 Sample Size Public Universities - 10 years old and above

\begin{tabular}{lccc}
\hline University & Deans/Directors & Senior Management & Total \\
\hline University of Nairobi & 33 & 22 & 55 \\
Moi University & 27 & 16 & 42 \\
Kenyatta University & 20 & 11 & 31 \\
Masinde Muliro & 19 & 5 & 24 \\
Egerton University & 15 & 4 & 19 \\
Maseno University & 13 & 3 & 15 \\
Kisii University & 6 & 2 & 8 \\
Technical University of Mombasa & 4 & 2 & 6 \\
Technical University of Kenya & 11 & 2 & 13 \\
Dedan Kimathi University & 5 & 2 & 7 \\
\hline Total & $\mathbf{1 5 3}$ & $\mathbf{6 8}$ & $\mathbf{2 2 1}$ \\
\hline
\end{tabular}




\subsection{Data Processing and Analysis}

After the data collection the questionnaire were coded, entered and analyzed using Statistical Packages for Social Scientists (SPSS) version 22. The social demographic characteristics of the respondents were analyzed using descriptive statistics. According to Brace, Kamp \& Snelgar (2003) descriptive statistics are statistical tools used to summarize large volumes of data with very few figures. Simple regression analysis was carried out to show the nature of the relationship between employee core competencies and employee performance, (Kothari, 2011). The level of significance was tested at $5 \%$ whereby if the $p$ value was less than 0.05 then there was enough evidence to reject the null hypothesis and accept the alternative hypothesis. Regression model was of the form;

$\mathrm{Y}=\beta_{0}+\beta_{1} \mathrm{X}_{1}+\dot{\varepsilon}$

Where; $\mathrm{Y}=$ Employee Performance, $\mathrm{X}_{1}=$ Employee competencies Management.

\section{Findings and Discussions}

\subsection{Descriptive Statistics of Employee Competencies Management}

Employee competencies are those traits, skills or attributes that employees need to perform their jobs most effectively. Clearly, these competencies will vary by job and position, but there are some commonalities that apply to just about any job in just about any organization, (Garvey, 2013). Employee competencies management as a KM practice therefore focuses on the value of human capital which largely depends on the level of involvement of employees, the extent to which they want and can use their own potential to achieve the objectives of the company, (Alessandria \& Secundo, 2009).

Concerning respective universities employees' competencies as shown in Table 4.1 majority agreed or strongly agreed 42.1 percent that their universities had vision and mission statements that were clearly and easily understood by employees. Secondly, majority 51.5 percent agreed and 39.1 percent agreed that their universities recognized their knowledge as asset base. Majority 48 percent strongly agreed and $45.5 \%$ agreed that their university encouraged team work, discussions and collaboration to improve communication between colleagues. Further, majority 52.5 percent strongly agreed and 42.1 percent agreed that their universities discussed individual performance and evaluated areas which needed improvements. Majority 56.9 percent strongly agreed and 38.6 percent agreed that their universities encouraged employee's participation in decision making process and majority 57.4 percent and 39.1 percent agreed that their universities improved task efficiency through knowledge sharing using intranets and electronic bulletins.

These findings agreed with Stockley (2007) who argued that there is need to consistently audit critical competencies which are major determinants of their performance. Through it, individual skills gap can be easily identified and corrective measures adopted to enhance individual performance. Also, Eicker et al., (2014) supported on the idea to anchor employee competencies with organizational needs and this will enhance association with respective institution. These results were in congruence with Zaim et al., (2013) who reported that employee competencies had significant influence not only employee behaviour but also performance as well as turnover. Further, Sparl et al., (2013) called on adoption of robust employee skills management courtesy of which organization association will be created.

At the respective universities majority strongly agreed mean $=4.5$ and standard deviation of 0.8 that there are open to new ideas. Secondly, majority agreed mean $=3.7$ and standard deviation of 1.1 that their universities keep abreast on new developments in their areas. Thirdly, majority agreed mean $=3.9$ and standard deviation 1.1 that they effectively build networks and build alliances with key individual groups. Further, majority agreed mean = 4.1 and standard deviation of 0.8 that their employees are encouraged to held and respect each other. Moreover, majority either agreed mean $=4.1$ that they have common mission and feeling of belonging in a team or individual are assisted to achieve their potential through personal development. Majority 40.1 percent and 28.7 percent strongly agreed that their employees' inventory and skill gap is regularly updated and 27.7 percent agreed and 28.7 percent strongly agreed that their internal employees are given chance whenever vacancies arose. On average employees agreed mean $=4.1$ competencies management in public universities had influence on their performance. These findings mirrored Prusak (2013) who reported the need for patenting intellectual capacities so as to protect their talents. This was only achieved through continued knowledge sharing approaches, skills tracking and development of measures on how to acquire them. Through these strategies employee's motivation was enhanced and performance improved. Further, their mirrored Murtaza (2015) who called for organization investment in skills development and resources allocation on staff careers progression. In contrast, the study refuted Yusuf and Wanjau (2014) who reported that employees in state corporation has deficit skills which hampered their performance in Kenya national treasury. 
Table 4.1 Descriptive Statistics of Employee Competencies Management

\begin{tabular}{|c|c|c|c|c|c|c|c|}
\hline \multirow[b]{3}{*}{ My university } & \multirow[b]{3}{*}{ SD } & \multicolumn{4}{|c|}{$\mathrm{n}=\mathbf{2 0 2}$} & \multirow{3}{*}{$\begin{array}{l}\text { Me } \\
\text { an }\end{array}$} & \multirow{3}{*}{$\begin{array}{l}\text { Std. } \\
\text { Dev }\end{array}$} \\
\hline & & \multicolumn{3}{|c|}{$\mathbf{N}$} & \multirow{2}{*}{$\begin{array}{l}\mathbf{S} \\
\mathbf{A}\end{array}$} & & \\
\hline & & $\mathbf{D}$ & $\mathbf{S}$ & $\mathbf{A}$ & & & \\
\hline Has mission and vision statements that are clear and easily & & & 5. & 42 & 42 & & \\
\hline understood by employees & 5 & 5 & 9 & .1 & .1 & 4.1 & 1.1 \\
\hline & & & & 39 & 51 & & \\
\hline Recognizes my knowledge as part of their asset base & 3 & 3 & 3 & 6 & .5 & 4.3 & 0.9 \\
\hline Encourages teamwork, discussions and collaboration to improve & & 1. & & 45 & & & \\
\hline communication between colleagues & 1 & 5 & 4 & .5 & 48 & 4.4 & 0.7 \\
\hline Assesses my individual work performance regularly and discuss & & 2. & 1. & 42 & 52 & & \\
\hline improvement areas & 1.5 & 5 & 5 & .1 & .5 & 4.4 & 0.8 \\
\hline Provides opportunities for continuous growth and development of & & & 2. & 42 & 48 & & \\
\hline employees & 2.5 & 4 & 5 & 6 & .5 & 4.3 & 0.9 \\
\hline Encourages active employee participation in the process of decision & & 1. & 1. & 38 & 56 & & \\
\hline making & 1.5 & 5 & 5 & 6 & .9 & 4.5 & 0.7 \\
\hline Employees improve task efficiency by sharing knowledge through & & & 1. & 39 & 57 & & \\
\hline intranets and electronic bulletins' & & 2 & 5 & .1 & .4 & 4.5 & 0.6 \\
\hline At my university & & & & & & & \\
\hline & & 3. & & 39 & 55 & & \\
\hline Am open to new ideas and approaches & 1.5 & 5 & 0 & .1 & .9 & 4.5 & 0.8 \\
\hline & & 11 & 16 & 40 & 26 & & \\
\hline I keep abreast of new developments in my discipline area & 5 & 9 & .3 & .6 & .2 & 3.7 & 1.1 \\
\hline I effectively develop networks and build alliances with key & & 7. & 8. & & 28 & & \\
\hline individuals and groups & 6.4 & 9 & 9 & 48 & .7 & 3.9 & 1.1 \\
\hline & & 3. & 11 & & 32 & & \\
\hline Employees are encouraged to help and respect each other & 1.5 & 5 & .4 & 51 & .7 & 4.1 & 0.8 \\
\hline & & 5. & 13 & 35 & 44 & & \\
\hline There is a common mission and feeling of belonging to a team & 2 & 4 & .4 & .1 & .1 & 4.1 & 1.0 \\
\hline Individual team members are helped to reach their potential through & & 5. & 18 & 36 & 38 & & \\
\hline personal development & 1 & 9 & .3 & .1 & .6 & 4.1 & 0.9 \\
\hline Different methods are used for encouraging employees to share & & 11 & 16 & 36 & 31 & & \\
\hline knowledge like training, mentoring, coaching etc. & 3.5 & .4 & .8 & .6 & .7 & 3.8 & 1.1 \\
\hline & & 11 & 11 & 41 & 31 & & \\
\hline There are processes to determine gaps in individual skills & 3.5 & 9 & .9 & .6 & .2 & 3.9 & 1.1 \\
\hline There are processes to track on employee's progress in skills & 11. & 15 & 26 & 27 & 18 & & \\
\hline acquisition & 4 & .8 & .7 & .2 & .8 & 3.3 & 1.3 \\
\hline Employee skills, inventory and skill gap analysis are regularly & & 6. & 20 & 40 & 28 & & \\
\hline updated & 4 & 9 & .3 & .1 & .7 & 3.8 & 1.0 \\
\hline & & 21 & 13 & 27 & 28 & & \\
\hline Internal employees are given priority when a vacancy occurs & 8.4 & .3 & .9 & .7 & .7 & 3.5 & 1.3 \\
\hline Overall Average & & & & & & 4.1 & 1.0 \\
\hline
\end{tabular}

\subsection{Agreement on Employee Performance in Public Universities}

As shown in Table 4.2 majority 41.1 percent of respondents strongly agreed and 31.2 percent agreed that they are able to meet their targets in Kenyan public universities. Secondly, majority mean $=3.8$ and standard deviation $=$ 1.2 agreed that they are able to fulfill their responsibilities. Thirdly, majority 47.5 percent agreed and 32.7 percent that there are collaborate well with their respective employees. Further, majority 36.1 percent agreed and 25.2 percent strongly agreed that employees in public universities understand each other well. Similarly, 51.1 percent strongly agreed and 40.1 percent agreed that they understand other employees very well. In addition, majority mean $=4.4$ either agreed that they come up with creative ideas in their work place or are open to criticism. Also, majority mean $=4.4$ either agreed that they try to learn from feedback they receive from fellow employees or they take challenging tasks whenever they are available. Majority strongly agreed mean $=4.5$ that either they start new tasks once they have completed others or they seek for help when need arises. Further, majority mean $=4.3$ agreed that they take initiatives whenever they are problems to be solved.

At their respective work places majority agreed mean $=4.4$ agreed that in public universities in Kenya they continuously update their job knowledge. Also, majority mean $=4.3$ agreed that they work at keeping their job skills up to date. Further, majority strongly agreed mean $=4.6$ and 4.5 that they come up with creative solutions 
to new problems and they are able to cope with unpredictable situations at work respectively. Finally, majority mean $=4.4$ either agreed that they easily adjust to changes in their work place or recover fast after difficult work situations in their places of work. On overall majority agreed on current state of their job performance $($ mean $=$ 4.3; standard deviation $=0.9$ ).

Table 4.2 Agreement on Status of Employee Performance

\begin{tabular}{|c|c|c|c|c|c|c|c|}
\hline & \multicolumn{5}{|c|}{$\mathrm{n}=\mathbf{2 0 2}$} & \multirow[b]{2}{*}{$\begin{array}{l}\text { Mea } \\
\text { n }\end{array}$} & \multirow[b]{2}{*}{$\begin{array}{l}\text { Std. } \\
\text { Dev }\end{array}$} \\
\hline & $\begin{array}{l}\text { S } \\
\mathbf{D}\end{array}$ & D & $\mathbf{N}$ & $\mathbf{A}$ & SA & & \\
\hline I am able to meet my targets & 4 & 6.9 & 16.8 & 31.2 & 41.1 & 4.0 & 1.1 \\
\hline I am able to fulfill my responsibilities & 5 & 15.3 & 13.4 & 27.7 & 38.6 & 3.8 & 1.2 \\
\hline Collaborations with others goes well & 3 & 4.5 & 12.4 & 47.5 & 32.7 & 4.0 & 0.9 \\
\hline $\begin{array}{l}\text { Other employees understand me well when I tell } \\
\text { them something }\end{array}$ & 7.9 & 13.9 & 16.8 & 36.1 & 25.2 & 3.6 & 1.2 \\
\hline $\begin{array}{l}\text { I understand others well when they tell me } \\
\text { something }\end{array}$ & 1.5 & 2.5 & 5 & 40.1 & 51 & 4.4 & 0.8 \\
\hline Communication with others leads to desired results & 1 & 3.5 & 6.9 & 28.7 & 59.9 & 4.4 & 0.8 \\
\hline I come up with creative ideas at work & & & 3.5 & 39.6 & 56.9 & 4.5 & 0.6 \\
\hline $\begin{array}{l}\text { I take initiative when there is a problem to be } \\
\text { solved }\end{array}$ & 4.5 & 1.5 & 2.5 & 39.6 & 52 & 4.3 & 0.9 \\
\hline I start new tasks myself when new ones are finished & 0.5 & 1 & 3.5 & 38.1 & 56.9 & 4.5 & 0.7 \\
\hline I ask for help when needed & 0 & & 5 & 42.6 & 52.5 & 4.5 & 0.6 \\
\hline I am open to criticism of my work & 2.5 & 1 & 6.9 & 31.2 & 58.4 & 4.4 & 0.9 \\
\hline $\begin{array}{l}\text { I try to learn from the feedback I get from others on } \\
\text { my work }\end{array}$ & 2 & 4.5 & 5 & 31.2 & 57.4 & 4.4 & 0.9 \\
\hline I take on challenging work tasks, when available & 3.5 & 0 & 5.9 & 34.2 & 56.4 & 4.4 & 0.9 \\
\hline I work at keep my job knowledge up-to-date & 1 & 4 & 2.5 & 38.6 & 54 & 4.4 & 0.8 \\
\hline I work at keeping my job skills up-to-date & 3.5 & 3 & 5.4 & 34.7 & 53.5 & 4.3 & 1.0 \\
\hline I come up with creative solutions to new problems & 0 & 0 & 5.9 & 32.2 & 61.9 & 4.6 & 0.6 \\
\hline $\begin{array}{l}\text { I am able to cope with uncertain and unpredictable } \\
\text { situations at work }\end{array}$ & 0 & 3 & 6.9 & 25.2 & 64.9 & 4.5 & 0.8 \\
\hline I easily adjust to changes in my work & 1 & 2.5 & 4.5 & 37.1 & 55 & 4.4 & 0.8 \\
\hline $\begin{array}{l}\text { I recover fast, after difficult situations or setbacks } \\
\text { at work } \\
\text { Overall average }\end{array}$ & 1 & 3.5 & 4 & 39.1 & 52.5 & $\begin{array}{l}4.4 \\
4.3\end{array}$ & $\begin{array}{l}0.8 \\
\mathbf{0 . 9}\end{array}$ \\
\hline
\end{tabular}

*SD-Strongly Disagree, D-Disagree, NS- Not sure, A-Agree, SA-Strongly agree

4.3 Employees Competencies Management has no Significant Influence on Employee Performance in Public Universities in Kenya

The hypothesis stated that employees' competencies management had no significant influence on employee performance in public universities in Kenya. Simple linear regression analysis was adopted and the study findings with an R squared of 0.592 revealed that 59.2 percent of changes in employee performance in public universities in Kenya was explained by employees' competencies management while the remaining percentage can be explained by other factors unaccounted for in the model.

Table 4.3 Model Summary on Test for Significant Influence of Employees Competencies Management on Employees Performance in Public Universities in Kenya

\begin{tabular}{ccccc}
\hline Model & R & R Square & Adjusted R Square & Std. Error of the Estimate \\
\hline 1 & $.770 \mathrm{a}$ & 0.592 & 0.59 & 0.594 \\
\hline
\end{tabular}

a Predictors: (Constant), ECM

As shown in Table 4.4 on analysis of variance on influence of employees' competencies management on employee performance in public universities in Kenya. There was significant influence of employees' competencies management on employee performance in public universities in Kenya $(\mathrm{F}=290.716$, $\mathrm{p}$ value $<0.05)$.

Table 4.4 Analysis of Variance on Test for Significant Influence of Employees Competencies Management on Employees Performance in Public Universities in Kenya

\begin{tabular}{|c|c|c|c|c|c|c|}
\hline Model & & Sum of Squares & df & Mean Square & $\mathbf{F}$ & Sig. \\
\hline \multirow{3}{*}{1} & Regression & 102.532 & 1 & 102.532 & 290.716 & $.000 \mathrm{~b}$ \\
\hline & Residual & 70.537 & 200 & 0.353 & & \\
\hline & Total & 173.069 & 201 & & & \\
\hline
\end{tabular}

a Dependent Variable: EMP

b Predictors: (Constant), ECM 
As shown in Table 4.5 there was positive and significant influence of employees' competencies management on employees' performance in public universities in Kenya $(\beta=0.082$, p value $<0.05)$. Since $p$ value was less than 5 percent then at 5 percent level of significance, we reject the null hypothesis and accept an alternative that there was positive and significant influence between employees' competencies management and performance in public universities in Kenya. Hence an increase in employees' competencies increases employee performance by 0.082 units. These findings agreed with Stockley (2007) who reported positive and significant relationship between critical competencies and employee performance. Also, Eicker et al., (2014) reported positive and significant influence of employee competencies on employee satisfaction. Similarly, Zaim et al., (2013) reported positive influence of employee competencies on organization output.

These findings agreed with (Zaim et al., 2013; Sparl \& Znidarsic, 2009; Prusak, 2013; Murtaza, 2015; Ngesa et al., 2014) who reported positive and significant effect of employee competencies management on employee performance. They contrasted Ramirez, et al., (2007) who reported inverse and significant influence of employee competencies management on employee performance. These findings are in line with knowledge economy theory which perceive knowledge creation is an asset base which leads to competitive advantage in an organization.

$\mathrm{EMP}=-0.027+0.802 \mathrm{ECM}$ 4.1

Table 4.5 Regression Coefficient on Test for Significant Influence of Employees Competencies Management on Employees Performance in Public Universities in Kenya

\begin{tabular}{clccccc}
\hline Model & & \multicolumn{2}{c}{$\begin{array}{c}\text { Unstandardized Coefficients } \\
\text { B }\end{array}$} & $\begin{array}{c}\text { Standardized Coefficients } \\
\text { Beta }\end{array}$ & t & Sig. \\
& & -0.027 & 0.042 & & -.649 & 0.517 \\
1 & (Constant) & 0.802 & 0.047 & 0.77 & 17.05 & 0.000 \\
\hline
\end{tabular}

a Dependent Variable: EMP

\section{Conclusion and Recommendations}

Research findings indicated that majority of employees were conversant with their universities mission and vision statements, universities perceived knowledge management as an asset base, team work and coherent communication guidelines were laid down by respective universities. Also, public universities continuously discussed and evaluated individual employees' performance, universities employees shared information through inter and intranet mechanisms. Universities created sense of belongingness, had knowledge inventory management which eased skills gaps identification and internal promotions were availed to employees periodically. It can be concluded that an increase in employee competencies increased employee performance in Kenyan public universities. This calls for clarification of organization vision and mission statements amongst employees, creation of harmonious team groups in respective university departments and creation of information sharing platforms through intra and internet facilities. Further, employees ought to be encouraged to be open to new approaches and ideas, adoption of alternative mentoring methods and creation of employees' skills inventory and robust inventory skills management to be adopted to ease filling of employees' gaps.

From the study findings the following conclusions can be drawn. Since there was positive and significant influence of employee competencies management on employee performance in Kenyan public universities. There is need for Kenyan public universities to enhance their competencies mapping strategies and competencies monitoring and evaluation. This can be achieved through creation of growth opportunities for employees and adoption of participatory decision-making strategies amongst employees. Further, public universities should be open to new ideas, innovation and creativity since these will ease sharing of knowledge. Also, alternative approaches should be developed to gather and consolidate information and knowledge tracking devices ought to be deployed in different department so as to optimize benefits associated with business intelligence gathering strategies.

\section{References}

Alai, D., Kramer D., \& Montier, R. (2006). Competency Models Develop Top Performance T + D, 4(3), 47-50.

Baskerville, R.,\& Dulipovici A. (2006). The Theoritical Foundations of Knowledge Management. Knowledge Management Research and Practices, 4(2), 83-105.

Bassi, L.J. (1997). Harnessing the Power of Intellectual Capacity. Training \& Development, 51(12), 25-30.

Boyatsiz, R.E. (2008). Competencies in the 21st century.Journal of Management Development, 27(1), 5-12.

Brenner, P. M. (1999). Motivating Knowledge Workers: The Role Of The Workplace, QualityProgress, 32 (1), 33 37.

Brooking, A. (1997). Intellectual Capital: Core Asset for the Third Millennium Enterprise, International Thomson Business Press, New York.

Cranfield, D.J.,\&Taylor, J. (2011). Knowledge Management and Higher Education: a UK Case Study. The Electronic Journal of Knowledge Management.6(2), 85-100.

Edvardsson, I.R. (2008). HRM and knowledge management, Employee Relations, 30(5), 553-561. 
Eicker, S., Kochbeck, J. \& Schuler, P.M. (2014). Employee Competencies for Business Process Management, Available athttp//www.softec.wiwi.uni.due.de/uploads, retrieved on $3^{\text {rd }}$ March 2017.

Garvey, S. (2010). Knowledge as an Asset: Applicability in Large Firms. Journal of Management, 18(7), $218-232$.

Ibua, M. P. (2014). The influence of institutional factors and job-related attitudes on the relationship between employee empowerment and performance of public universities in Kenya. Unpublished PhD Thesis. School of Business, University of Nairobi.

Kodwani, A.D. (2009). Competency Mapping. Paradigm (Institute of Management Technology), 13(2), 117-118.

Kothari, C.R. (2011). Research Methodology: Methods and Techniques. ${ }^{\text {th }}$ Edition. International (P) Ltd., Publishers, India.

Kothari, C.R. (2013). Quantitative Methods. New Age International (P) Ltd. Publishers, India.

Lei, X, (2014).A Study on the Enterprises' Internal and External Knowledge Network Management.WHICEB Proceedings. Paper 22.

Murtaza, Z. (2015). An Empirical study of Competency Mapping of the Employees in the Tourism Sectorin Jumuu\& Kashmir, India. An Executive Level Perspective. Journal f Business Management in Social Sciences Research, 4(2), 203-208.

Ngesa, A.O., Mbithi, S., \& Musiega, D. (2016). Influence of Perfrmance Management Practices on Employee Engagement in Public Universities in Kenya: A Case Study of Kibabii University, Kenya.Journal of Precious Engineering Research \& Applications, 1(3), 25-35.

Omatayo, F. O. (2015). Knowledge Management as an important tool in Organizational Management: A Review of Literature. Library Philosopy and Practice (e-journal). 1238.

Oso, W.\& Onen, D. (2009).General guide to writing research proposal and Report:A handbook for beginners ( 2nd Edition.). Kampala: Makerere University Printer.

Polit, D. F., \& Beck, C. T. (2004). Nursing research: Appraising evidence for nursing practice. ( $7^{\text {th }}$ Ed.).Philadelphia: Wolters Klower/Lippincott Williams \& Wilkins.

Prahald, C. K., \& Hamel, G. (1990). The Core Competence of the Corporation. Harvard Business Review, 68(3), 78-91.

Prusak, L. (1997). Knowledge in Organizations, Butterworth-Heinemann, USA. Psychologist, 20: 321-33.

Prusak, L. (1997). Knowledge in Organizations, Butterworth-Heinemann, USA. Psychologist, 20: 321-33.

Prusak, R. (2013). The impact of Employee Competencies management as part of the human capital on the intellectual capital implementing process. Management, 20(1), 27-39.

Roos, J. \& Von Krogh, G. (1996). The epistemological challenge: managing knowledge and intellectual capital. European Management Journal,14(4), 333-337.

Schiuma, G. (2012). Managing knowledge for business performance improvement.Journal of Knowledge Management, 16(4), 515-522.

Sekaran, U., \& Bougie, R. (2013). Research Methods for Business: A Skill-Building Approach. 6th Edition, Wiley, New York.

Stockley, D. (2007). Total Management Concept - Definition Explanation, e-mail newsletter, Available at:www.derekstockley.com.ad.Accessed on 10th Sept. 2017

Sveiby, K.E. (1997).The New Organizational Wealth: Managing and Measuring Knowledge-Based Assets, Berrett-Koehler Publishers Inc.

Tapsell, S.(1998). Making Money From Brainpower: The new wealth of nations, Management - Auckland, 45(6), 36-43.

Ulrich, D. (1998). Intellectual Capital Equals Competence X Commitment.Sloan Management Review, 39(2), 1526.

Wiig K.M. (1997). Integrating intellectual capital and knowledge management. Long Range Planning, 30: 399405.

Woodman, M., \& Zade, A. (2011). Five grounded principles for developing knowledge management systems. Electronic Journal of Knowledge Management, 10(2), 328-339.

Zaim, H., Yasai, M.F., \& Unal, O.F. (2013). Analyzing the effects of Individual competencies on Performance: A field study in Services Industry in Turkey. Journal of Global Strategic Management, 7(2), 67-77.

Zook, C., (2007).Finding Your Next Core Business. Harvard Business Review 